\title{
Characterization of purified and Xerogel immobilized Novel Lignin Peroxidase produced from Trametes versicolor IBL-04 using solid state medium of Corncobs
}

Muhammad Asgher ${ }^{1}$, Hafiz Muhammad Nasir lqbal ${ }^{1 *}$ and Muhammad Irshad²

\begin{abstract}
Background: Cost-effective production of industrially important enzymes is a key for their successful exploitation on industrial scale. Keeping in view the extensive industrial applications of lignin peroxidase (LiP), this study was performed to purify and characterize the LiP from an indigenous strain of Trametes versicolor IBL-04. Xerogel matrix enzyme immobilization technique was applied to improve the kinetic and thermo-stability characteristics of LiP to fulfil the requirements of the modern enzyme consumer sector of biotechnology.

Results: A novel LiP was isolated from an indigenous T. versicolor IBL-04 strain. T. versicolor IBL-04 was cultured in solid state fermentation (SSF) medium of corn cobs and maximum LiP activity of $592 \pm 6 \mathrm{U} / \mathrm{mL}$ was recorded after five days of incubation under optimum culture conditions. The crude LiP was 3.3-fold purified with specific activity of $553 \mathrm{U} / \mathrm{mg}$ after passing through the DEAE-cellulose and Sephadex-G-100 chromatography columns. The purified LiP exhibited a relatively low molecular weight $(30 \mathrm{kDa})$ homogenous single band on native and SDS-PAGE. The LiP was immobilized by entrapping in xerogel matrix of trimethoxysilane (TMOS) and proplytetramethoxysilane (PTMS) and maximum immobilization efficiency of $88.6 \%$ was achieved. The free and immobilized LiPs were characterized and the results showed that the free and immobilized LiPs had optimum pH 6 and 5 while optimum temperatures were $60^{\circ} \mathrm{C}$ and $80^{\circ} \mathrm{C}$, respectively. Immobilization was found to enhance the activity and thermo-stability potential of LiP significantly and immobilized LiP remained stable over broad $\mathrm{pH}$ and temperature range as compare to free enzyme. Kinetic constants $K_{\mathrm{m}}$ and $V_{\max }$ were 70 and $56 \mu \mathrm{M}$ and 588 and $417 \mathrm{U} / \mathrm{mg}$ for the free and immobilized LiPs, respectively. Activity of this novel extra thermo-stable LiP was stimulated to variable extents by $\mathrm{Cu}^{2+}, \mathrm{Mn}^{2+}$ and $\mathrm{Fe}^{2+}$ whereas, Cystein, EDTA and $\mathrm{Ag}^{+}$showed inhibitory effects.

Conclusions: The indigenously isolated white rot fungal strain T. versicolor IBL-04 showed tremendous potential for LiP synthesis in SSF of corncobs in high titters $(592 \mathrm{U} / \mathrm{mL}$ ) than other reported Trametes (Coriolus, Polyporus) species. The results obtained after dual phase characterization suggested xerogel matrix entrapment a promising tool for enzyme immobilization, hyper-activation and stabilization against high temperature and inactivating agents. The $\mathrm{pH}$ and temperature optima, extra thermo-stability features and kinetic characteristics of this novel LiP of T. versicolor IBL-04 make it a versatile enzyme for various industrial and biotechnological applications.
\end{abstract}

Keywords: T. versicolor IBL-04, LiP, Immobilization, Xerogel, Characterization, Hyper-activation, Thermo-stabilization, Inactivation tolerance

\footnotetext{
*Correspondence: nasir_pk99@hotmail.com

'Industrial Biotechnology Laboratory, Department of Chemistry and

Biochemistry, University of Agriculture, Faisalabad, Pakistan

Full list of author information is available at the end of the article
} 


\section{Background}

Fungi from basidiomycetes group are known ligninolytic enzymes producers. Lignin modifying enzymes (LMEs) are rarely produced by bacteria, yeasts and most fungi but frequently occur in the fermented culture broth of white rot fungi $[1,2]$. White rot fungi (WRF) are so far exclusive in their potential to entirely degrade all the components of lignocellulosic materials and this capability is due to their extra cellular nonspecific LMEs which function together with $\mathrm{H}_{2} \mathrm{O}_{2}$ and secondary metabolites. The aptitude of Trametes versicolor to depolymerize lignin has been investigated from a physiological point of view. In P. chrysosporium and $T$. versicolor lignin peroxidases have been found to appear during the secondary metabolism $[1,3,4]$. Lignin peroxidases (LiPs) are glycosylated proteins that functionally require $\mathrm{H}_{2} \mathrm{O}_{2}$ for the oxidation of lignin related aromatic structures. A large number of substrates and by-products of lignin degradation, such as vanillic acid, chlorogenic acid, veratric acid, and veratryl alcohol, have been tested for their ability to boost up ligninase activity [5]. Veratryl alcohol a secondary metabolite produced by ligninolytic WRF plays an important role in LiP catalysis. The kinetic analysis has revealed that cationic radical of veratryl alcohol converts LiP (II) and/or LiP (III) to LiP and improves its catalytic cycle [6]. LiPs from various WRF including Trametes versicolor and Pleurotus ostreatu differ from the other oxidoreductases in that they have low $\mathrm{pH}$ optima varying between $\mathrm{pH} 2-5$ and much higher redox potentials [7].

LiP is a biotechnologically important enzyme having potential applications to degrade highly toxic phenolic compounds from bleach plant effluents. LiPs and other ligninolytic enzymes from WRF find numerous applications in various industrial processes such as degradation of dyes, bioremediation, delignification for ethanol production, oxidation of organic pollutants, biosensors development, textile bio-finishing, beverage processing, wastewater detoxification, denim stone washing and detergent manufacturing [1,2,8-12]. Significant efforts have been made to convert lignocellulosic residues to valuable products such as bio-fuels, chemicals and animal feed with the help of ligninolytic enzymes (LiP, MnP and laccase) of WRF, many of which have been successful.

Enzyme immobilization has revolutionized the field of enzyme biotechnology. Entrapment, adsorption and surface binding are the most frequently employed methods that have been applied recently for enzyme immobilization. Entrapment is preferred over surface binding as this method is easier and cheaper and the structure of the enzyme remains secure [13]. Recently, the physical characteristics of xerogels have been manipulated for enzyme immobilization. Hydrophobic xerogels have the ability to produce enzymes in defined thin films that are thermostable and have the potential to catalyze reactions under wide environmental conditions [3]. Moreover, xerogel polymers are non-toxic and do not swell in aqueous or organic solvents, thus preventing the leaching of entrapped enzyme and allowing the enzymes to maintain their native structures. Immobilization of enzymes presents additional advantages including, improved resistance to thermal and chemical inactivation and remarkable storage and operational stability. In spite of the clear advantages of enzyme immobilization, only about $20 \%$ of bio-catalytic processes involve immobilized enzymes. However, over the last few years a number of interesting achievements and patent applications have been reported [14], indicating that enzyme immobilization has entered into a thrilling new stage.

T. versicolor is one of the most potent lignin degrading microorganisms that produce extracellular peroxidases under optimum growth conditions [5]. The occurrence of the ligninolytic enzymes in the $T$. versicolor genome makes it an attractive fungus for miscellaneous biotechnological and environmental applications. In our previous studies $[2,4,15,16]$, we have successfully investigated the extracellular ligninolytic enzymes ( $\mathrm{MnP}, \mathrm{LiP}$ and laccase) synthesis potential of different locally isolated indigenous WRF strains including Trametes versicolor IBL-04 under solid and liquid state fermentation based on varying lignocellulosic substrates and dye decolorization. Although considerable work has been reported on LiP from different fungal species but there are very few reports on purification, characterization and immobilization of LiP produced from Trametes versicolor. In this study for the first time T. versicolor IBL-04 LiP was immobilized by xerogel entrapment method with an objective of dual phase characterization of novel thermo-stable LiP to investigate its potential for industrial applications.

\section{Results and discussion Production of LiP}

T. versicolor IBL-04 was cultivated on solid substrate fermentation medium of corncobs moistened $(60 \% \mathrm{w} / \mathrm{w}$ moisture) with Kirk's basal medium of $\mathrm{pH} 4.0$ and incubated at $30^{\circ} \mathrm{C}$ for five days under previously optimized SSF growth conditions [4]. Maximum LiP activity of $592 \pm 6 \mathrm{U} / \mathrm{mL}$ was recorded when corncobs supplemented with glucose and yeast extract in $25: 1 \mathrm{C} / \mathrm{N}$ ratio, $1 \mathrm{~mL}$ of $1 \%$ tween- 80 as surface active agent, and $\mathrm{ZnSO}_{4}$ as metal ion source was inoculated with $5 \mathrm{~mL}$ freshly prepared spore suspension of T. versicolor IBL-04 and fermented for 5 days under still culture SSF conditions at $30^{\circ} \mathrm{C}$. Extracellular ligninolytic enzymes production is strongly influenced by the nature and amount of nutrients and microelements in the growth substrate. Different WRF have particular responses to nutrients and show different growth and enzyme synthesis patterns during their growth on different substrates [17]. T. versicolor IBL-04 had an extraordinary potential to produced 
relatively higher amount of novel thermo-stable LiP through SSF of corncobs than those described in literature for different strains of Trametes versicolor, Cunninghamella elegans and Flavodon flavus [18-21].

\section{Purification of LiP}

The cell free crude enzyme extract had an initial LiP activity of $118400 \mathrm{U} / 200 \mathrm{~mL}$ and specific activity of 170 $\mathrm{U} / \mathrm{mg}$. LiP was maximally precipitated out at $80 \%$ ammonium sulphate saturation with specific activity of 248 $\mathrm{U} / \mathrm{mg}$ and 1.5-fold purification. By Sephadex G-100 column gel filtration chromatography, the enzyme was purified up to 2.6 -fold with specific activity of $440 \mathrm{U} / \mathrm{mg}$ and its purification increased to 3.3 -fold with specific activity of $553 \mathrm{U} / \mathrm{mg}$ after passing through the DEAECellulose ion exchange column (Table 1). Mtui and Nakamura [19] achieved 50-80\% $\left(\mathrm{NH}_{4}\right)_{2} \mathrm{SO}_{4}$ saturation, followed by chromatographic purification techniques for the recovery of pure LiP. Roushdy et al. [18] achieved 2.76 purification fold with specific activity of $119.34 \mathrm{U} / \mathrm{mg}$ using Sephadex G-100 gel permeation of LiP after $80 \%$ ammonium sulfate saturation.

\section{Molecular mass estimation by electrophoresis}

The purified LiP was resolved on native and SDS-PAGE and found to be a homogenous monomeric protein, as evident by single homogenous band corresponding to $30 \mathrm{kDa}$ (Figure 1). The T. versicolor IBL-04 LiP was different in molecular mass from previously reported LiPs from Cunninghamella elegans and Phanerochaete sordida YK-624 (50 kDa) [18,22], Hexagona tenuis MTCC 1119 (48 kDa) [23], Flavodon flavus (46 kDa) [19], Loweporus lividus MTCC-1178 (40 kDa) [24] and Trametes versicolor (40 kDa) [25].

[Lane $\mathrm{M}$, Molecular weights in $\mathrm{kDa}$ of standard marker; ( $\beta$-Galactosidase, 116 kDa; Phosphorylase B, 97 kDa; albumin, $66 \mathrm{kDa}$; ovalbumin, $45 \mathrm{kDa}$; carbonic anhydrase, $30 \mathrm{kDa}$ and trypsin inhibitor, $21 \mathrm{kDa}$ ); lane 1 , Crude enzyme extract lane 2, Purified LiP in SDS; lane 1 and 2 in native, Purified LiP (30 kDa)].

\section{Immobilization of LiP}

The activity profiles of free and immobilized LiPs showed that specific activities of xerogel immobilized LiP was 1.27 fold higher as compared to free enzyme as shown in

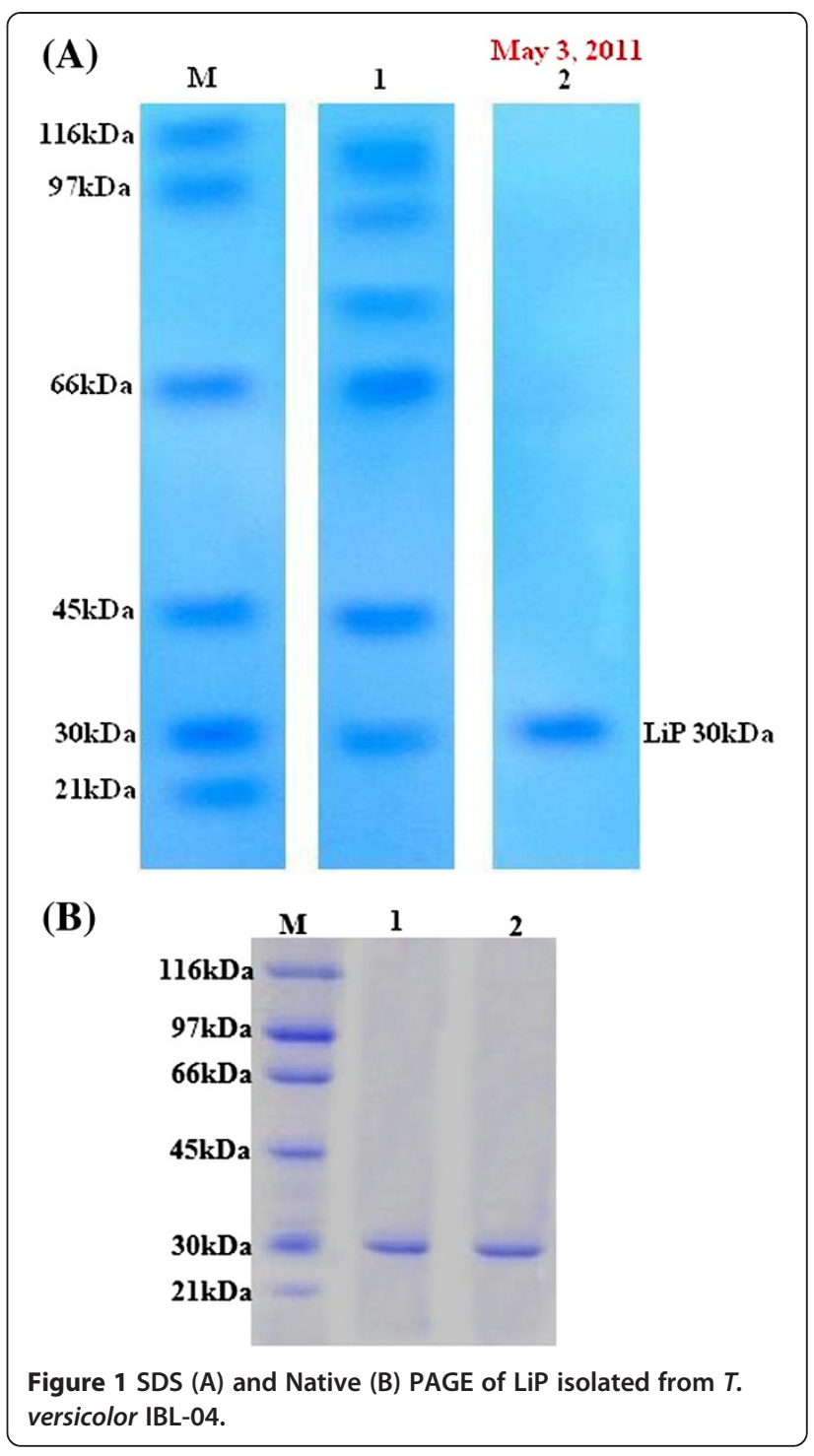

Table 2. The influence of enzyme concentration on the immobilization efficiency was studied using enzyme in the range of $2-10 \mathrm{mg} / \mathrm{mL}(563 \mathrm{U} / \mathrm{mg}$ ). The fraction containing $2 \mathrm{mg} / \mathrm{mL}$ enzyme (563 U/mg) concentration showed maximum immobilization efficiency (88.6\%). The immobilization efficiency of gel matrix decreased to $51.2 \%$ with increasing concentrations of enzyme (Table 2). Entrapment of LiP in xerogel matrix involves adsorption phenomenon that has been reported as the best method

Table 1 Purification summary of LiP produced by T. versicolor IBL-04

\begin{tabular}{|c|c|c|c|c|c|c|}
\hline $\begin{array}{l}\text { Purification } \\
\text { steps }\end{array}$ & $\begin{array}{l}\text { Total volume } \\
(\mathrm{mL})\end{array}$ & $\begin{array}{c}\text { Total enzyme activity } \\
\text { (U) }\end{array}$ & $\begin{array}{l}\text { Total Protein content } \\
(\mathrm{mg})\end{array}$ & $\begin{array}{l}\text { Specific activity } \\
\text { (U/mg) }\end{array}$ & $\begin{array}{l}\text { Purification } \\
\text { fold }\end{array}$ & $\begin{array}{c}\% \\
\text { Yield } \\
\end{array}$ \\
\hline Crude enzyme & 200 & 118400 & 698 & 170 & 1 & 100 \\
\hline$\left(\mathrm{NH}_{4}\right)_{2} \mathrm{SO}_{4}$ precipitation & 25 & 13375 & 54 & 248 & 1.5 & 11.3 \\
\hline Sephadex-G-100 & 12 & 5724 & 13 & 440 & 2.6 & 4.8 \\
\hline DEAE-Cellulose & 9 & 3870 & 7 & 553 & 3.3 & 3.2 \\
\hline
\end{tabular}


Table 2 Specific activities* of free and immobilized LiP with immobilization efficiency ${ }^{* *}$

\begin{tabular}{lccc}
\hline $\begin{array}{l}\text { LiP } \\
\text { concentration } \\
(\mathbf{m g} / \mathbf{m L})\end{array}$ & $\begin{array}{c}\text { Specific activity } \\
\text { of free LiP } \\
(\mathbf{U} / \mathbf{m g})\end{array}$ & $\begin{array}{c}\text { Specific activity } \\
\text { of immobilized LiP } \\
(\mathbf{U} / \mathbf{m g})\end{array}$ & $\begin{array}{c}\text { Immobilization } \\
\text { efficiency } \\
\text { (\%) }\end{array}$ \\
\hline 2 & 580 & 666 & 88.6 \\
4 & 598 & 790 & 82.2 \\
6 & 644 & 865 & 73.4 \\
8 & 702 & 933 & 62.6 \\
10 & 788 & 999 & 51.2 \\
\hline
\end{tabular}

*Specific activities were calculated in $\mathrm{U} / \mathrm{mg}$ of triplicate means.

**Immobilization efficiency was calculated as the ratio of the enzyme

entrapped (difference between the enzyme loaded and the enzyme in the supernatant after washing) $\times 100$.

for immobilization of enzymes [3]. Previously, entrapment of LiP from $P$. chrysosporium in xerogels caused hyperactivation but an increase in hydrophobic character above certain optimum limits caused a decrease in LiP activity [3]. The results obtained by the xerogel entrapment method for the present LiP immobilization are comparable to those obtained by other methods such as the covalent bonding of the enzyme on siliceous cellular foams (McFs), Sepabeads EC-EP3 and Dilbeads NK supports or immobilization by the formation of cross-linked enzyme aggregates $[9,26]$. However, the covalent binding strategy adopted in the above mentioned studies was much more expensive as compare to the xerogel matrix entrapment method due to the requirement of a coupling agent such as glutareldehyde.

\section{Characterization of free and immobilized LiP Effect of $\mathrm{pH}$ on LiP activity and stability}

The $\mathrm{pH}$-activity profile of free LiP displayed optimal activity at $\mathrm{pH} 6$ whereas, immobilization hyperactivated the LiP and slightly shifted $\mathrm{pH}$ optima towards more acidic $\mathrm{pH}$ range. Immobilization also enhanced the resistance of LiP against $\mathrm{pH}$ variation. Results of stability profile showed that free LiP was only stable for $1 \mathrm{~h}$ in a $\mathrm{pH}$ range of 3.0 to 6.0 and start loosing activity at higher $\mathrm{pH}$ values steadily. The xerogel entrapment enhanced the $\mathrm{pH}$ stability of LiP for longer time period of $24 \mathrm{~h}$ that was much higher than the free enzyme (Figure 2). Earlier studies [7,27] reported optimum activities of various WRF LiPs to vary between $\mathrm{pH} 2-5$. Alam et al. [28] reported that the LiP produced from $P$. chrysosporium showed more than $80 \%$ of the maximum activity at optimum $\mathrm{pH} 5$, while according to Rodríguez-Couto and Sanroman [29] LiP from P. chrysosporium was optimally active at $\mathrm{pH}$ 4.2. It was observed that after immobilization, the optimum $\mathrm{pH}$ of LiP was shifted slightly toward the acidic range possibly due to the buffering effect of the carrier surface. This phenomenon was also reported by Erdemir et al. [30], who observed a slight optimum $\mathrm{pH}$ shift from 7 to 6 for LiP due to immobilization, but this smaller difference was due to the different method of immobilization, as well as the nature of the supporting matrix that was calyx[n]arene.

\section{Effect of temperature on LiP activity and stability}

The free LiP from $T$. versicolor IBL-04 was optimally active at $60^{\circ} \mathrm{C}$ and further increase in temperature caused its deactivation, while xerogel entrapped LiP showed optimum activity at temperatures higher than $60^{\circ} \mathrm{C}$. As compared to free enzyme xerogel entrapped LiP had an extraordinary thermo-stability for up to $24 \mathrm{~h}$ incubation at $80^{\circ} \mathrm{C}$ without losing much of its activity (Figure 3). As compared to previously reported LiPs the $T$. versicolor IBL-04 LiP had greater thermo-stability suggesting its potential for biotechnological applications. Relatively greater activity and high thermo-stability are attractive and desirable characteristics of an enzyme for industrial applications [15]. LiP from Loweporus lividus MTCC-1178 was optimally active at $24^{\circ} \mathrm{C}$ [24], LiP from $P$. chrysosporium showed better thermo-stability and was optimally active at $55^{\circ} \mathrm{C}$ [28], and that from $P$. chrysosporium was stable at $34^{\circ} \mathrm{C}$ [29]. Immobilization to a solid support causes
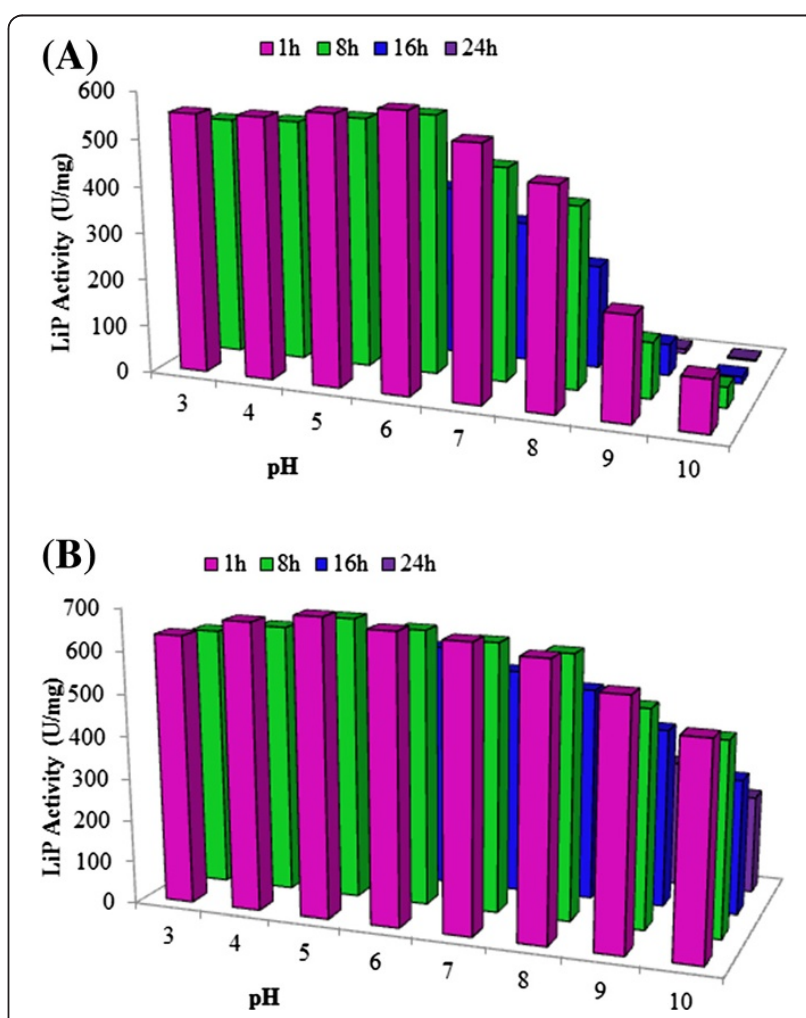

Figure 2 Effect of different $\mathrm{pH}$ on the activity and stability of purified free (A) and xerogel matrix immobilized (B) $T$.

versicolor IBL-04 LiP. 
changes in the enzyme conformation and thus increases stability towards heat denaturation. Similar hyperthermostablization of other enzymes in hydrophobic xerogels has also previously been reported [3].

\section{Effect of substrate concentration: Determination of $K_{m}$ and $V_{\text {max }}$}

Varying concentrations of veratryl alcohol $(\mu \mathrm{M})$ were plotted against the respective initial specific activities $\left(\mathrm{V}_{\mathrm{o}}\right)$ of free and immobilized LiP. Michalis-Menten kinetics yielded a hyperbolic curve. Lineweaver-Burk double reciprocal plots (Figure 4) were constructed. The $K_{\mathrm{m}}$ and $V_{\max }$ values for free LiP were $70 \mu \mathrm{M}$ and $417 \mathrm{U} / \mathrm{mg}$ as compared to $56 \mu \mathrm{M}$ and $588 \mathrm{U} / \mathrm{mg}$, respectively for immobilized LiP. The lower value of $K_{\mathrm{m}}$ and higher $\mathrm{V}_{\max }$ values for immobilized enzyme indicated that immobilization enhanced the substrate affinity and catalytic efficiency of LiP. Asgher et al. [3] reported that immobilized enzymes have the best catalyzing power as well as good interaction for their substrate. There is slight difference in the $K_{\mathrm{m}}$ and $V_{\max }$ values for T. versicolor IBL-04 LiP than other reported LiPs. The $K_{\mathrm{m}}$ values for veratryl alcohol and $\mathrm{H}_{2} \mathrm{O}_{2}$ for $\mathrm{LiP}$ from Loweporus lividus MTCC-1178 were 58 and $83 \mathrm{mM}$, respectively

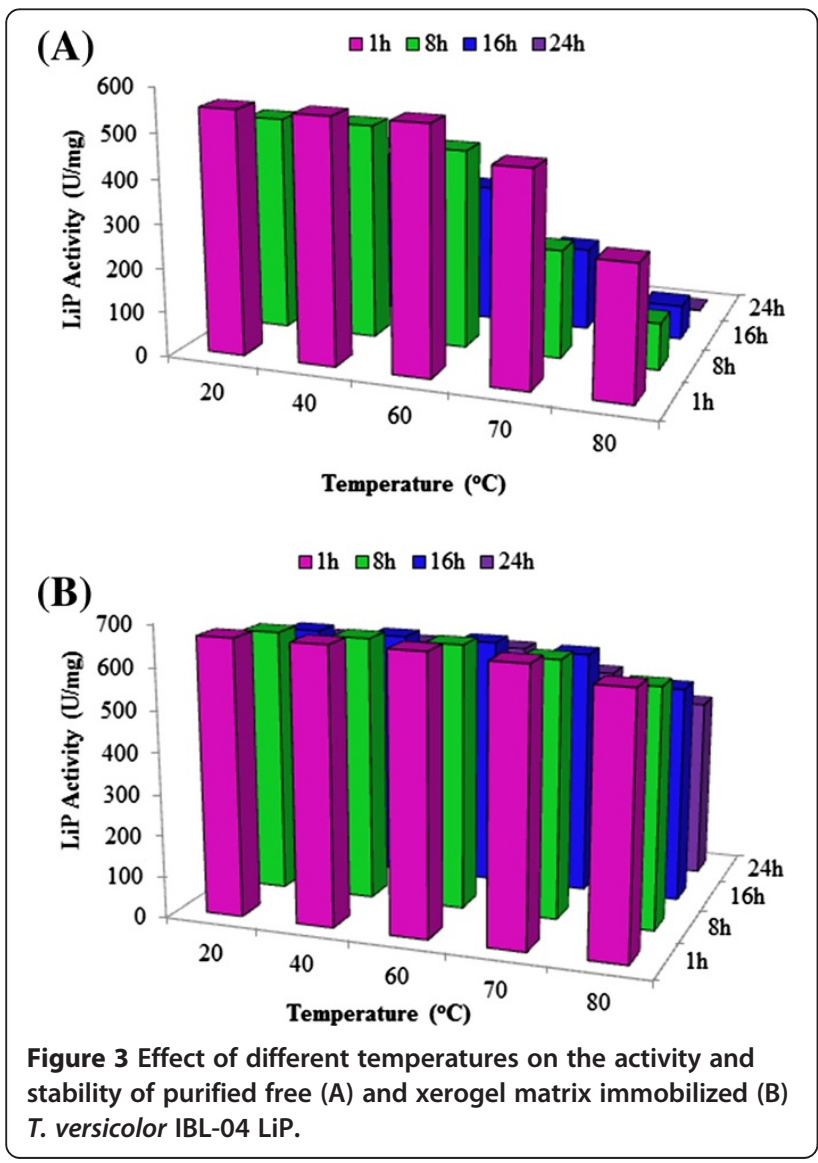

[24]. In another study the $K_{\mathrm{m}}$ for LiP was $167 \mu \mathrm{M}$ using veratryl alcohol as substrate [31].

\section{Effect of activators/inhibitors on free and immobilized LiP} The stimulatory/inhibitory effects of different organic compounds (EDTA \& Cystein) and metal ions $\left(\mathrm{Cu}^{2+}\right.$, $\left.\mathrm{Fe}^{2+} \& \mathrm{Ag}^{+}\right)$on free and entrapped LiP was investigated. Results showed that LiP was completely inhibited by cystein while it was partially inhibited with EDTA. Among the metal ions used, only $\mathrm{Ag}^{+}$caused LiP inhibition to variable extent whereas, $\mathrm{Cu}^{2+}$ and $\mathrm{Fe}^{2+}$ were activators of $\mathrm{LiP}$ at low concentration whereas (Figure 5). The xerogel entrapped LiP was found to exhibit significant tolerance against inactivation by cystein, EDTA and $\mathrm{Ag}^{+}$. EDTA is a metal chelating agent that has ability to bind the inorganic prosthetic groups of enzymes leading to inhibitory effect on enzymes. In many previous studies metal ions like $\mathrm{Hg}^{2+}$ and $\mathrm{Ag}^{+}$have been reported as stronger inhibitors of extra cellular peroxidases of WRF, while $\mathrm{Fe}^{3+}, \mathrm{Ca}^{2+}$ and $\mathrm{Ni}^{2+}$ did not cause any alteration in LiP activity [2]. Low concentrations of heavy metals ions are necessary for the development of the ligninolytic enzyme system of various WRF. Addition of $\mathrm{Zn}^{2+}$ and $\mathrm{Cu}^{2+}$ into the cultivation medium at low concentrations has been reported to increase LiP activity [15].

\section{Conclusions}

In conclusion, $T$. versicolor IBL-04 showed tremendous potential for LiP synthesis in SSF of corncobs in high titters $(592 \mathrm{U} / \mathrm{mL})$, than previously reported Trametes species. The extracellular LiP from $T$. versicolor IBL-04 had lowered molecular as compare to most WRF LiPs. T. versicolor IBL-04 LiP successfully immobilized with immobilization efficiency of $88.6 \%$ by xerogel entrapment in a matrix of TMOS and PTMS. Dual phase characterization showed that immobilization enhanced LiP activity, stability over broad $\mathrm{pH}$ range (3-8) and

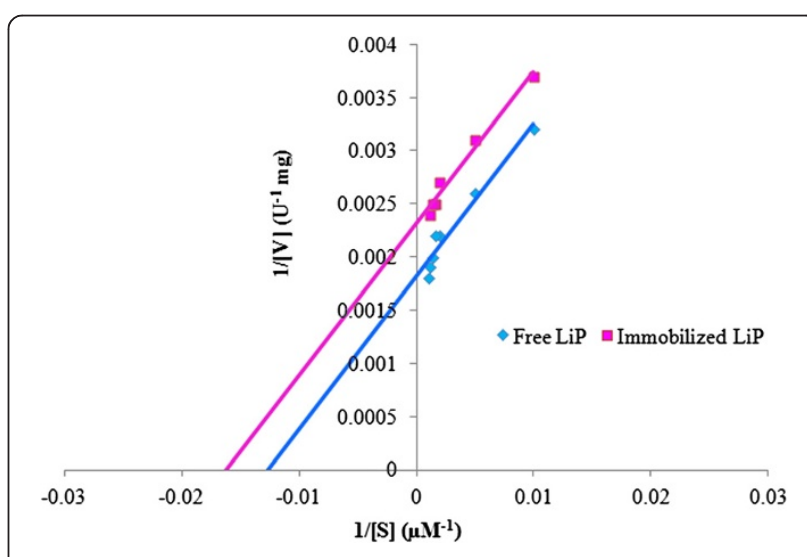

Figure 4 Lineweaver-Burk reciprocal plot: Determination of $K_{\mathrm{m}}$ and $V_{\max }$ for free and immobilized LiP. 


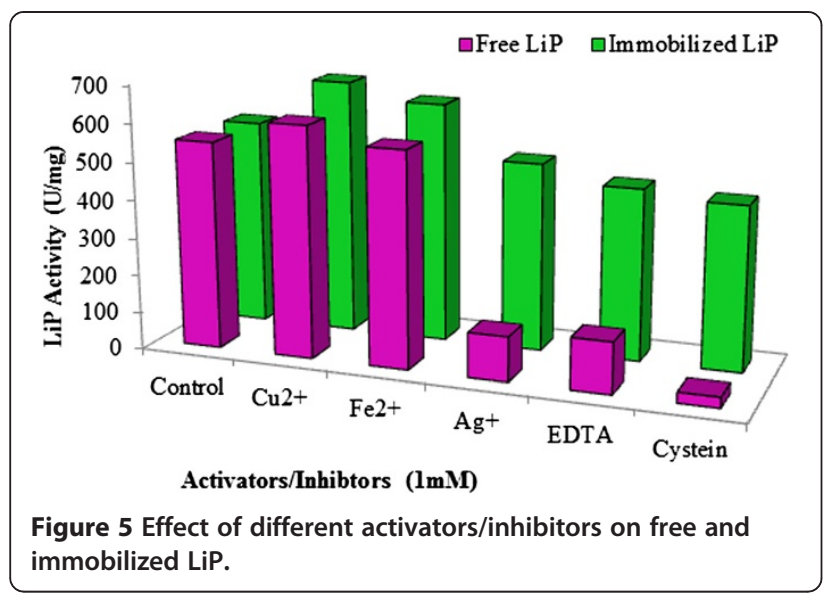

thermotolerance in $20-80^{\circ} \mathrm{C}$ temperature range for extended time period of $24 \mathrm{~h}$. Immobilization also enhanced the substrate affinity and catalytic efficiency of LiP as evidenced by lower $K_{\mathrm{m}}$ and high $V_{\max }$ values. The xerogel entrapped LiP had significantly higher tolerance against inactivating agents as compared to free enzyme. Results of dual phase characterization suggested that xerogel matrix entrapment is a promising tool for hyperactivation and stabilization of LiP making it a valuable and versatile enzyme for various industrial and biotechnological applications.

\section{Methods}

\section{Chemicals and lignocellulosic substrate}

Trimethoxysilane, proplytetramethoxysilane, polyvinyl alcohol, Sephadex G-100, 2, 2'-azino-bis-3-ethylbenzothiazoline-6-sulfonic acid (ABTS), Coomassie Brilliant Blue G-250, sodium dodecylsulphate (SDS), trizma base and standard Protein markers were purchased from Sigma-Fluka-Aldrich (USA). All other chemicals were of analytical grade and were mainly purchased from Merck (Germany) and Scharlau (Spain). Corncobs used a substrate in SSF was collected from CPC-Rafhan, Faisalabad, Pakistan. The substrate was chopped, oven dried $\left(60^{\circ} \mathrm{C}\right)$, ground to fine particle size $(40 \mathrm{~mm})$ and stored in air tight plastic jars to avoid moisture. The substrate was used in SSF without any pretreatment.

Micro-organism and preparation aqueous spore inoculum The indigenous strain $T$. versicolor IBL-04 available in Industrial Biotechnology Laboratory, UAF, Pakistan was used for LiP production. Aqueous spore suspension was prepared by growing the $T$. versicolor IBL-04 in glucose (1\%) supplemented Kirk's basal nutrient medium [32]. The medium was sterilized $\left(121^{\circ} \mathrm{C}\right)$ in laboratory scale autoclave (Sanyo, Japan) for $15 \mathrm{~min}$. It was allowed to cool and was inoculated with loopful culture of $T$. versicolor IBL-04 from PDA slants in laminar air flow (Dalton, Japan). The inoculated flask was incubated for 5 days at $30^{\circ} \mathrm{C}$ in an orbital shaker (120 rpm) (Sanyo-Gallemkemp, UK) to get homogenous spore suspension $\left(10^{6}-10^{8}\right.$ spores $/ \mathrm{mL}$ ).

\section{LiP production and extraction protocol}

Production of LiP from T. versicolor IBL-04 was carried out in $250 \mathrm{~mL}$ Erlenmeyer flasks under some previously optimized fermentation conditions [4]. Triplicate flasks containing $5 \mathrm{~g}$ corncobs were moistened $(60 \% \mathrm{w} / \mathrm{w})$ with Kirk's nutrient medium, sterilized and inoculated with $5 \mathrm{~mL}$ of freshly prepared homogeneous fungal spore suspension under sterile conditions in laminar air flow. The inoculated flasks were allowed to ferment at $30^{\circ} \mathrm{C}$ in a still culture SSF incubator (EYLA SLI-600ND, Japan) for 5 days. After the expiry of 5 days fermentation time, the LiP was extracted by adding $100 \mathrm{~mL}$ distilled water to the fermented mesh and flasks were shaken at $120 \mathrm{rpm}$ for $30 \mathrm{~min}$. The contents of fermentation flask were filtered (Whatman No.1 filter paper) and washed thrice with distilled water. The filtrates were centrifuged at $4,000 \times \mathrm{g}$ for $10 \mathrm{~min}$ and clear supernatants were pooled as crude extract for LiP assay and purification studies.

\section{LiP activity assay and protein content determination}

LiP activity of the supernatant was determined by the method of Tien and Kirk [32] following the $\mathrm{H}_{2} \mathrm{O}_{2}$ dependent oxidation of veratryl alcohol to verataldehyde at $25^{\circ} \mathrm{C}$ using UV/Visible spectrophotometer (T60, PG Instruments, UK). The assay mixture contained $1 \mathrm{~mL}$ tartarate buffer $(100 \mathrm{mM})$ of $\mathrm{pH} 3,1 \mathrm{~mL}$ of $4 \mathrm{mM}$ veratryl alcohol, $500 \mu \mathrm{L}$ of $0.2 \mathrm{M} \mathrm{H}_{2} \mathrm{O}_{2}$ and $100 \mu \mathrm{L}$ of enzyme extract. The activity of reaction mixture was measured against reagent blank at $310 \mathrm{~nm}\left(\boldsymbol{\epsilon}_{310}=9300\right)$. The recorded activities were expressed as $\mathrm{U} / \mathrm{mL}$ while one unit LiP activity was defined as the amount of enzyme required to oxidize one $\mu \mathrm{mol}$ of VA per minute at $25^{\circ} \mathrm{C}$. To determine the amount of protein contents of the crude and purified enzyme extracts, the Bradford micro assay was followed [33] using Bovine serum albumin (BSA) as standard.

\section{Purification of LiP}

Crude LiP extract was centrifuged at $4,000 \times \mathrm{g}$ for $15 \mathrm{~min}$ and cell-free supernatant was first brought to $40 \%$ saturation by the gradual addition of solid crystals of ammonium sulfate and kept for overnight at $4^{\circ} \mathrm{C}$. The resulting precipitate was collected by centrifugation $(4,000 \times \mathrm{g})$ for $15 \mathrm{~min}$ at $4^{\circ} \mathrm{C}$ and in the supernatant more crystals of ammonium sulfate were added in order to achieve $80 \%$ saturation. It was again kept for overnight at $4^{\circ} \mathrm{C}$ and centrifuged as described previously. After centrifugation the sediments were dissolved in a minimal volume of $100 \mathrm{mM}$ Tartarate buffer of $\mathrm{pH} 3$. The solution was kept in a dialysis bag and after sealing 
securely it was dialyzed against the same buffer. The dialyzate was concentrated by ultra-filtration and applied to Sephadex G-100 (Sigma, USA) glass column $(2 \times 20 \mathrm{~cm})$. Tartarate buffer $(100 \mathrm{mM})$ with $0.15 \mathrm{M}$ $\mathrm{NaCl}$ was used as elution buffer and the flow rate

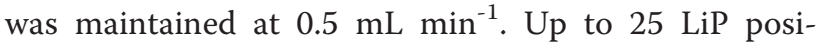
tive fractions were pooled, concentrated by ultra filtration and used to determine the enzyme activity as well as the protein content as described earlier. For further purification, the fractions collected after passing through Sephadex G-100 chromatographic column were loaded on DEAE cellulose ion-exchange column $(2 \times 20 \mathrm{~cm})$. The fractions were collected with flow rate of $1 \mathrm{~mL}$ per min and both the LiP activity and protein contents were determined for each fraction as mentioned in the previous section.

\section{Molecular mass estimation by electrophoresis}

To determine the relative molecular mass of purified LiP, sodium dodecyl sulphate (SDS) and Native poly acrylamide gel electrophoresis (PAGE) was performed on a stacking and separating gel according to the method of Laemmli [34] using Mini-gel electrophoresis (V-GES, Wealtec, USA). The molecular mass of the purified LiP was estimated in comparison to standard molecular weight markers (standard protein markers, 21-116 kDa; Sigma, USA). The protein bands were visualized by staining with Coomassie Brilliant Blue G250 (Sigma, USA) after documentation.

\section{Immobilization of LiP}

The trimethoxysilane (TMOS) and proplytetramethoxysilane (PTMS) were used in molar TMOS: PTMS (T: P) ratios of 1:5 to prepare xerogel matrix for LiP entrapment. Trametes versicolor IBL-04 LiP was suspended in de-ionized water in five different fractions $(2-10 \mathrm{mg} / \mathrm{mL})$ having $563 \mathrm{U} / \mathrm{mg}$ LiP activity and centrifuged to remove insoluble components. The supernatant fluid $(400 \mu \mathrm{L})$ from each fraction was added to a mixture of aqueous sodium fluoride, polyvinyl alcohol and water. The solution was shaken and PTMS was added followed by TMOS. The reaction mixture was shaken for $20 \mathrm{sec}$ on vortex mixer and placed in ice bath until gel formation occurred. At the end activity of xerogel entrapped LiP was determined, as described in the previous section for free enzyme.

\section{Characterization of free and immobilized LiP}

The kinetic and catalytic properties of free and immobilized LiP were studied through characterization by studying the effect of $\mathrm{pH}$, temperature, substrate concentration and activators/inhibitors on their activities.

\section{Effect of $\mathrm{pH}$ on LiP activity and stability}

The effect of varying $\mathrm{pH}(\mathrm{pH} 3-10)$ on the activities of free and entrapped LiP was investigated using the following buffers $(0.2 \mathrm{M})$ : sodium melonate buffer, $\mathrm{pH} 3.0$ \& 4.0; citrate phosphate, $\mathrm{pH} 5.0$ \& 6.0; sodium phosphate, $\mathrm{pH} 7.0$ \& $\mathrm{pH}$ 8.0; and potassium carbonate buffer, $\mathrm{pH} 9.0 \& \mathrm{pH}$ 10.0. The free and gel entrapped LiPs were incubated at room temperature $\left(25^{\circ} \mathrm{C}\right)$ for $15 \mathrm{~min}$. While, for stability assay, LiP was incubated at room temperature $\left(25^{\circ} \mathrm{C}\right)$ for up to $24 \mathrm{~h}$ without substrate before running the normal activity assay and residual activity of LiP was checked after 1, 8, 16 and $24 \mathrm{~h}$.

\section{Effect of temperature on LiP activity and stability}

Effect of varying temperatures on LiP activity and stability was also studied. Both the free and xerogel entrapped LiP were incubated with citrate phosphate buffer of $\mathrm{pH}$ 6.0 and 5.0, respectively, for $15 \mathrm{~min}$ at varying temperatures $\left(20-80^{\circ} \mathrm{C}\right)$ before running the enzyme assay. For stability studies, the enzymes were incubated at varying temperatures for $24 \mathrm{~h}$ in the absence of substrate before running the normal activity assay and residual enzyme activities were determined after 1, 8, 16 and $24 \mathrm{~h}$.

\section{Effect of substrate concentration: Determination of $K_{m}$ and $V_{\text {max }}$}

The Michalis-Menten kinetic constants $K_{\mathrm{m}}$ and $V_{\max }$ for free and entrapped LiP were determined from MichalisMenten and Lineweaver-Burk reciprocal plots using varying concentrations of veratryl alcohol $(100-1000 \mu \mathrm{M})$ as substrate. To determine the kinetic constants free and xerogel entrapped LiP were incubated for $15 \mathrm{~min}$ at room temperature $\left(25^{\circ} \mathrm{C}\right)$ using citrate phosphate buffer of $\mathrm{pH} 6.0$ and 5.0, respectively, before carrying out enzyme assay.

\section{Effect of activators/inhibitors on free and immobilized LiP}

Effect of various organic (EDTA \& Cystein) and inorganic ions $\left(\mathrm{Cu}^{2+}, \mathrm{Fe}^{2+} \& \mathrm{Ag}^{+}\right)$as possible stimulators or inhibitors on purified free and xerogel entrapped LiP from $T$. versicolor IBL-04 was studied. The enzyme activities in each case were determined under standard assay conditions as described earlier (incubation time $15 \mathrm{~min}$ at $25^{\circ} \mathrm{C}$ in citrate phosphate buffer of $\mathrm{pH} 6.0$ and 5.0 for free and xerogel entrapped LiP, respectively).

\section{Statistical analysis}

All the experiments and analyses were performed in triplicate and the data were statistically evaluated according to Steel et al. [35].The means and standard errors of means (Mean \pm S.E) were computed for each treatment and S.E values have been displayed as Y-error bars in figures. 


\section{Competing interests}

The authors have no competing interests.

\section{Authors' contributions}

HMNI (Research Associate of the project) participated in designing of the study and carried out the experimental work on microbial cultivation, LiP production \& extraction, purification, xerogel entrapment immobilization and kinetic characterization of free and immobilized LiP and participated in drafting the manuscript. All the research work was carried out under supervision of MA (Principal Investigator of the project) who designed and coordinated the experiments. MA and Ml also interpreted the data and drafted the manuscript. All authors read and approved the revised manuscript.

\section{Acknowledgements}

The present study was a part of the research project focused on development of ligninolytic enzymes for industrial applications. The financial support for this project by Higher Education Commission, Islamabad, Pakistan is thankfully acknowledged.

\section{Author details}

'Industrial Biotechnology Laboratory, Department of Chemistry and Biochemistry, University of Agriculture, Faisalabad, Pakistan. ${ }^{2}$ Department of Biochemistry, Nawaz Sharif Medical College, University of Gujrat, Gujrat, Pakistan.

Received: 28 February 2012 Accepted: 23 July 2012

Published: 3 August 2012

\section{References}

1. Asgher M, Bhatti HN, Ashraf M, Legge RL: Recent developments in biodegradation of industrial pollutants by white rot fungi and their enzyme system. Biodegradation 2008, 19:771-783.

2. Asgher M, lqbal HMN, Asad MJ: Kinetic characterization of purified laccase produced from Trametes versicolor IBL-04 in solid state bio-processing of corncobs. Bioresources 2012, 7:1171-1188.

3. Asgher M, Asad MJ, Bhatti HN, Legge RL: Hyperactivation and thermostablization of Phanerochaete chrysosporium lignin peroxidase by immobilization in xerogels. World J Microbiol Biotechnol 2007, 23:525-531.

4. lqbal HMN, Asgher M, Bhatti HN: Optimization of physical and nutritional factors for synthesis of lignin degrading enzymes by a novel strain of Trametes versicolor. Bioresources 2011, 6:1273-1278.

5. Collins PJ, Field JE, Teunissen P, Dobson ADW: Stabilization of Lignin Peroxidases in White Rot Fungi by Tryptophan. Appl Environ Microbiol 1997, 63:2543-2548.

6. Lan J, Wang F, Huang XR, Li YZ, Qu YB, Gao PJ: Studies on the hydrogen peroxide regulated veratrylalcohol mediated oxidation of Pyrogallol red catalyzed by lignin peroxidase. Acta Chimi $\operatorname{Sin} 2006,64: 463-468$.

7. Snajdr J, Baldrian P: Temperature effects the production, the activity and stability in lignolytic enzymes in Pleurotus ostreatu and Trametes versicolor. Folia Micbiol 2007, 52:498-502.

8. Colao MC, Lupino S, Garzillo AM, Buonocore V, Ruzzi M: Heterologous expression of Icc1 gene from Trametes trogii in Pichia pastoris and characterization of the recombinant enzyme. Microb Cell Fact 2006, 5:31.

9. Kunamneni A, Ghazi I, Camarero S, Ballesteros A, Plou FJ, Alcalde M: Decolorization of synthetic dyes by laccase immobilized on epoxyactivated carriers. Proc Biochem 2008, 43:169-178.

10. Kunamneni A, Camarero S, García-Burgos C, Plou FJ, Ballesteros A, Alcalde M: Engineering and Applications of fungal laccases for organic synthesis. Microb Cell Fact 2008, 7:32.

11. Kim J-M, Park S-M, Kim D-H: Heterologous expression of a tannic acidinducible laccase3 of Cryphonectria parasitica in Saccharomyces cerevisiae. BMC Biotechnol 2010, 10:18

12. Reiss $R$, Ihssen J, Thöny-Meyer L: Bacillus pumilus laccase: a heat stable enzyme with a wide substrate spectrum. BMC Biotechnol 2011, 11:9.

13. Minovska V, Winkelhausen E, Kuzmanova S: Lipase immobilized by different techniques on various support materials applied in oil hydrolysis. J Serb Chem Soc 2005, 70:609-624.

14. Spahn C, Minteer SD: Enzyme immobilization in biotechnology. Recent Patents Eng 2008, 2:195-200.
15. Asgher M, lqbal HMN: Characterization of a novel manganese peroxidase purified from solid state culture of Trametes versicolor IBL-04. Bioresources 2011, 6:4317-4330.

16. Asgher M, Azim N, Bhatti HN: Decolorization of practical textile industry effluents by white-rot fungus Coriolus versicolor IBL-04. Biochem Eng J 2009, 47:61-65.

17. Selvam K, Swaminathan K, Rasappan K, Rajendran R, Pattabhim S: Decolorization and dechlorination of a pulp and paper industry effluent by Thelephora sp. Ecol Environ Conserv 2006, 12:223-226.

18. Roushdy MM, Abdel-Shakour EH, El-Agamy El: Biotechnological Approach for Lignin Peroxidase (LiP) Production from Agricultural Wastes (Rice Husk) by Cunninghamella elegans. J Am Sci 2011, 7:6-13.

19. Mtui G, Nakamura Y: Lignocellulosic enzymes from Flavodon flavus, a fungus isolated from Western Indian Ocean off the Coast of Dar es Salaam, Tanzania. Afr J Biotechnol 2008, 7:3066-3072.

20. Arora DS, Chander M, Gill PK: Involvement of lignin peroxidase, manganese peroxidase and laccase in degradation and selective ligninolysis of wheat straw. Int Biodet Biodeg 2002, 50:115-120.

21. Hossain SM, Anantharaman N: Activity enhancement of ligninolytic enzymes of Trametes versicolor with bagasse powder. Afr J Biotechnol 2006, 5:189-194.

22. Sugiura $M$, Hirai $H$, Nishida T: Purification and characterization of a novel lignin peroxidase from white-rot fungus Phanerochaete sordida YK-624. FEMS Microbiol Lett 2003, 224:285-290.

23. Yadav M, Singh SK, Yadav SK, Yadav KDS: Purification of lignin peroxidase from Hexagona tenuis MTCC 1119 and its kinetic properties in aqueous medium containing miscible organic solvents. Indian J Chem 2010, 49B:489-494.

24. Yadav M, Yadav P, Yadav KDS: Purification and characterization of lignin peroxidase from Loweporus lividus MTCC-1178. Eng Life Sci 2009, 9:124-129.

25. Sonoki T, Kajita S, Uesugi M, Katayama Y, limura Y: Effective Removal of Bisphenol a from Contaminated Areas by Recombinant Plant Producing Lignin Peroxidase. J Pet Environ Biotechnol 2011, 2:1-3.

26. Cabana H, Jones JP, Agathos SN: Preparation and characterization of cross-linked laccase aggregates and their application to the elimination of endocrine disrupting chemicals. J Biotechnol 2007, 132:23-31.

27. Yang JS, Yuan HL, Chen WX: Studies on extracellular enzymes of lignin degrading fungus Penicillium sp. P6. China Environ Sci 2004, 24:24-27.

28. Alam MZ, Mansor MF, Jalal KCA: Optimization of lignin peroxidase production and stability by Phanerochaete chrysosporium using sewagetreatment-plant sludge as substrate in a stirred-tank bioreactor. J Ind Microbiol Biotechnol 2009, 36:757-764.

29. Rodríguez-Couto S, Sanroman M: Application of solid-state fermentation to food industry-A review. J Food Eng 2006, 76:291-302.

30. Erdemir S, Sahin O, Uyanik A: Effect of the glutaraldehyde derivatives of Calix[n]arene as cross linker reagents on lipase immobilization. J Ind Phenom Macrocycl Chem 2009, 64:273-282.

31. Hayatsu R, Winans RE, Mcbeth RL, Scott RG, Moore LP, Studier MH: Ligninlike polymers in coal. Nature 1979, 278:41-43.

32. Tien M, Kirk TK: Lignin peroxidase of Phanerochaete chrysosporium. Methods Enzymol 1988, 33:569-575.

33. Bradford MM: A rapid and sensitive method for quantification of microgram quantities of protein utilizing the principle of protein dye binding. Anal Biochem 1976, 72:248-254.

34. Laemmli UK: Cleavage of structural proteins during assembly of head of bacteriophage T4. Nature 1970, 227:680-685.

35. Steel R, Torrie J, Dickey D: Principles and Procedure of Statistics. A biometrical approach. New York: WCB McGraw Hill Book Co Inc; 1997.

doi:10.1186/1472-6750-12-46

Cite this article as: Asgher et al:: Characterization of purified and Xerogel immobilized Novel Lignin Peroxidase produced from Trametes versicolor IBL-04 using solid state medium of Corncobs. BMC Biotechnology 2012 12:46. 